DOI: 10.22616/REEP.2019.008

\title{
Students' Evaluations about Prosocial and Violent Behaviour and Attitudes
}

\author{
Kristi Koiv $\mathrm{PhD}$ \\ University of Tartu, Estonia \\ kristi.koiv@ut.ee
}

\begin{abstract}
This cross-sectional study addressed to measure two aspects of students' evaluations across three school contexts: (1) frequency of prosocial and violent behaviour in peer and student-teacher relationships, and (2) attitudes toward prosocial and violent behaviour in peer and student-teacher relationships. Questionnaire data were drawn from study involving overall 514 students from Estonia: Students in juvenile correctional educational institutions $(\mathrm{N}=82)$, students with special needs in special schools $(\mathrm{N}=151)$, and students in mainstream schools $(\mathrm{N}=281)$, whereby the age of all subjects was 1417 year. Results of the study indicated that: (1) Prosocial attitude-behaviour consistency tended to exists among students in mainstream school and in special schools, but among juvenile delinquents inconsistency between prosocial attitudes and actions at relationships level was revealed - positive attitude with lowest frequency of action in student-teacher relations compared with student-student relations; and (2) violence attitude-behaviour consistency tended to exists in mainstream school and in special schools, whereby among juvenile delinquents inconsistency between violence attitudes and behaviour exists in relationship level - most negative attitudes with highest frequency of behaviour in student-teacher relations compared with student-student relations. Prosocial/violence attitude-behaviour relations may vary from school setting to school setting and from relationships levels - student-teacher, student-student, giving directions for prevention of and intervention in school violence.
\end{abstract}

Keywords: prosocial behaviour, violent behaviour, attitudes, adolescents, different school settings, psychology.

\section{Introduction}

Based on empirical evidence R. Veenstra (2006) concluded that research on the development of prosocial and antisocial (included violence) behaviour in childhood and adolescence has been rather independent branches of each other reflecting the advances of studies in which prosocial and antisocial behaviour examined concurrently, whereby existing studies (Krueger, Hicks, McGue, 2001) mix measures of behaviour with measures of attitudes in this area.

Prosocial behaviour is usually defined as behaviour intended to help others (Eisenberg, 1996) and involves sharing, cooperating, helping, feeling empathy, and caring for others (Radke-Yarrow, ZahnWaxler, Chapman, 1983). Violent behaviour can be defined as physical force exerted to cause damage, abuse, or injury reflecting subtype of broad category of behaviour - antisocial behaviour, which is act that violates the rules and laws of society (Connor, 2002).

Violence in school is a serious problem in contemporary schools and has documented in the literature internationally (Smith, 2003). Strong correlations between positive attitudes towards violence and aggressive (verbal, physical and relational) behaviour exist among boys and girls in adolescence (Vernberg, Jacops, Hershberger, 1999). Research (Gellman, Delucia-Waack, 2006) among perpetrators of school violence and nonviolent control participants have demonstrated a positive relationship between adolescents' attitudes toward violence and the use of violence, whereby it was found that attitudes towards violence had partial mediator role in the relationship between media-peer effects and physical violence among adolescents (Avci, Gucray, 2013). At the other side, prosocial adolescents were more prone to endorse prosocial values and mores (Carlo et al., 2003; 2011; Johnston, Krettenauer, 2011; Padilla-Walker, Carlo, 2007); and more sophisticated levels of prosocial moral reasoning have been shown to predict higher levels of prosocial and lower levels of aggressive behaviour among adolescents (Carlo et al., 1996; Eisenberg et al., 1995; Wyatt, Carlo, 2002), whereby this is consistent with results among delinquents showing lower scores on moral reasoning than non-delinquents (Stams et al., 2006). Also, P. Boxer, M.S. Tisak and S.E. Goldstein revealed that normative beliefs about aggression were positively associated with aggressive behaviour in early and middle adolescents, whereby these beliefs were negatively associated with one specific type of prosocial behaviour - proactive prosocial (manipulative, selfinterested, goal-directed) behaviour (Boxer, Tisak, Goldstein, 2004). 
Although prosocial and antisocial (included delinquent) behaviours are independent behavioural tendencies stemming from different dispositions among adults (Krueger, Hicks, McGue, 2001), findings suggested that they were related to each other, especially in early adolescence (Veenstra et al., 2008) when antisocial behaviour is at its peak. High levels of prosocial behaviour were accompanied by low levels of antisocial behaviour, and vice versa. Moreover, prosocial preadolescents had the highest level of socioeconomic status, effortful control, intelligence, academic performance, and peer acceptance, and the lowest level of peer rejection, bullying, and victimization; and antisocial preadolescents had the reverse levels of these variables being seriously at risk of life-course persistent antisocial behaviour according to T.E. Moffitt's (Moffitt, 1993) categorization.

Longitudinal research suggests that (pre)adolescents who engage in high levels of prosocial behaviours were less likely to exhibit number of antisocial (Carlo et al., 2011; Kokko et al, 2006) and delinquent (Pulkkinen, Tremblay, 1992) behaviours. Correlative studies provide evidence that specific forms of prosocial behaviour were linked to aggressive behaviours in adolescence: Compliant (helping when requested) and altruistic (acting without expectation of self-reward) forms of prosocial behaviours showed the strongest negative links to early adolescents' delinquent and physical and verbal aggressive behaviours (Carlo et al., 2014); proactive prosocial (manipulative, self-interested, and goal-directed acting) behaviour correlated positively with aggression, and uncorrelated with other prosocial behaviour (i.e., reactive, altruistic) among early and middle adolescents (Boxer, Tisak, Goldstein, 2004); physical aggression correlated negatively with altruistic and compliant forms of prosocial behaviour among late adolescent college students, whereby sympathy fully mediated the relations between compliant prosocial behaviours and physical aggression, and partially mediated the relations between altruism and physical aggression (McGinley, Carlo, 2007). Also, correlative (Ma et al., 2000) studies have revealed that peer relationships among adolescents were associated negatively with their antisocial behaviours, and teacher-student relationship associated positively with prosocial behaviours.

Furthermore, there exist some cross-sectional studies provided evidence for a group of adolescents that combine and a group of adolescents that lack both prosocial and antisocial behaviour (Pakaslahti, Keltikangas-Jarvinen, 2001), whereby of adolescents who had used both prosocial and antisocial strategies were popular among peers (Hawley, 2003; Kornbluh, Neal, 2016). With regard to the classification of T.E. Moffitt (1993) these juveniles tend to be adolescence-limited antisocial and during their adolescence, they start to engage in antisocial acts but were able to refrain from such activities if the costs of such behaviour increase.

The adolescence-limited group of antisocial behaviour of juveniles was indistinguishable from the lifecourse persistent group (Nagin, Farrington, Moffitt, 1995; Moffitt et al., 2001) indicating that life-course persistent antisocial behaviour was characteristic for juvenile delinquents in educational correctional institutions and adolescence-limited antisocial behaviour emerge among mainstream and special schools' students (Koiv, 2006). Also, the social-organizational context in three types of schools was different - schools' climate across two dimensions (teacher support and school policies against violence) and schools' safety was most favourable in mainstream schools and last favourable in juvenile correctional institutions, whereby middle ratings reflected special school pupils' opinions in the area of school climate and safety (Koiv, 2014).

The aim of the present study was twofold: to compare (1) the variance of prosocial and violent behaviour in peer and student-teacher relationships, and (2) the variance of attitudes towards prosocial and violent behaviour in peer and student-teacher relationships in the three educational contexts/settings: mainstream schools, special schools and juvenile correctional institutions.

\section{Methodology}

\section{Research questions}

The current study aimed to address two research questions. Whether there is a variation in prosocial attitudes and prosocial behaviour across different school context (mainstream school, special school, correctional institution) and across different relationships levels (student-student, student-teacher)?

Whether there is a variation in violence attitudes and violent behaviour across different school context (mainstream school, special school, correctional institution) types and across different relationships levels (student-student, student-teacher)? 


\section{Samples}

Data were drawn from study involving overall $51414-17$ years old $(\mathrm{M}=15.22 ; \mathrm{SD}=0.88)$ middle school students from Estonia: students in two juvenile correctional institutions $(\mathrm{N}=82$; boys: 65, girls: $27)$; students with special educational needs in three randomly selected special schools $(\mathrm{N}=151$; boys: 82, girls: 69); and students in nine randomly selected mainstream schools ( $\mathrm{N}=281$, boys: 151 , girls: 130).

\section{Instruments}

The first self-report instrument of the study was designed to measure the frequency of seven types of prosocial behaviour (cooperating, helping, inclusion, sharing, showing empathy, showing trustworthiness, supporting) and seven types of violent behaviour (insults, offensive remarks, physical attacks, ridiculing, shouting, threatening to hurt, and threatening with violence) in peer and studentteacher relations, viewing students as targets. Participants answered to each item describing prosocial behaviour using one of four Likert-type scale response ranging from $0=$ never to $3=$ very often. Average scores were calculated for the Frequency of Violent Behaviour scale and for the Frequency of Prosocial Behaviour scale, whereby higher scores indicated higher frequency of involvement. The Cronbach's alpha for the Frequency of Violent Behaviour scale was 0.90, and for the Frequency of Prosocial Behaviour scale was 0.89 .

The second instrument of the study was a self-report measure for evaluation of attitudes towards seven types of prosocial behaviour (cooperating, helping, inclusion, sharing, showing empathy, showing trustworthiness, and supporting) and towards seven types of violence (insults, offensive remarks, physical attacks, ridiculing, shouting, threatening to hurt, and threatening with violence) in peer and student-teacher relations. Items were scored on a five-point Likert-type scale, ranging from $1=$ strongly disagree to $5=$ strongly agree, whereby a higher score indicates a more favourable attitude. The average scores for Attitudes about Violent Behaviour scale and for the Attitudes about Prosocial Behaviour were calculated. The mean responses of prosocial attitudes scores were 3.37 and for violent attitudes scores 2.63 , which identified generally a neutral to a slightly above neutral attitude level. The Cronbach's alpha of the Attitudes about Violent Behaviour scale was 0.87 and 0.86 for the Attitudes about Prosocial Behaviour scale.

\section{Results and Discussion}

At first, the prevalence of violence and prosocial behaviour exhibited by the three groups of pupils in juvenile correctional educational institutions (training school), in special schools and in mainstream schools across two levels of relations in school setting - student-student and student-teacher, was calculated.

Using $t$-tests, differences between three study groups were significant comparing the frequency of violent behaviour in peer and student-teacher relations: The total scores of frequencies of violent behaviour were higher in juvenile correctional institutions compared with pupils' evaluations in special schools and mainstream schools. Research results indicated that the prevalence of prosocial behaviour was higher among mainstream and special school pupils compared with training school pupils' evaluations in peer relations and in student-teacher relations revealing statistically significant differences. Also, the results indicate that among juvenile delinquents the frequency of prosocial behaviour was lower (lowest in general) in student-teacher relations than in student-student relations; and the frequency of violent behaviour was higher (highest in general) in student-teacher relations than in student-student relations. Concerning with above mentioned results the opposite tendencies were revealed among other study-groups - relatively higher prevalence of violent behaviour in pupil-pupil relationships compared with in peer relationships. There were no other statistically significant differences between the groups (Table 1).

Secondly, there were clear tendencies in three groups of students concerning with the attitudes towards prosocial behaviour among student-student and student-teacher relationships - the higher ratings among mainstream and special school students compared with training school students (all statistically significant differences between comparison groups). Students' attitudes toward violent behaviour in student-student and student-teacher relationships were different in the three types of school - lower ratings of violence among training school students compared with special school and mainstream school students' evaluations in both types (student-student, student-teacher) relations. 
Table 1

Frequency of violent and prosocial behaviour among student-student and student-teacher relationships among pupils in three types of school (means, $t$-values)

\begin{tabular}{|c|c|c|c|c|c|c|c|}
\hline \multicolumn{2}{|c|}{$\begin{array}{c}\text { Frequency of prosocial or violent } \\
\text { behaviour }\end{array}$} & \multirow{2}{*}{$\begin{array}{c}\begin{array}{c}\text { Juvenile } \\
\text { correctional } \\
\text { institution } \\
\text { (A) }\end{array} \\
1.16\end{array}$} & \multirow{2}{*}{$\begin{array}{c}\begin{array}{c}\text { Special } \\
\text { schools } \\
\text { (B) }\end{array} \\
1.55\end{array}$} & \multirow{2}{*}{$\begin{array}{c}\begin{array}{c}\text { Main- } \\
\text { stream } \\
\text { schools } \\
\text { (C) }\end{array} \\
1.59\end{array}$} & \multirow{2}{*}{$\begin{array}{c}\begin{array}{c}\text { A vs. B } \\
\boldsymbol{t} \text {-value }\end{array} \\
4.01 * *\end{array}$} & \multirow{2}{*}{$\begin{array}{l}\begin{array}{c}\text { A vs. C } \\
t \text {-value }\end{array} \\
4.04 * *\end{array}$} & \multirow{2}{*}{$\begin{array}{c}\text { B vs. C } \\
\boldsymbol{t} \text {-value } \\
0.04\end{array}$} \\
\hline Student- & $\begin{array}{l}\text { Prosocial } \\
\text { behaviour (D) }\end{array}$ & & & & & & \\
\hline $\begin{array}{l}\text { Stuaent } \\
\text { relationships }\end{array}$ & $\begin{array}{l}\text { Violent behaviour } \\
\text { (E) }\end{array}$ & 1.62 & 1.32 & 1.21 & $2.99 * *$ & $2.78 * *$ & 0.12 \\
\hline \multirow{4}{*}{$\begin{array}{l}\text { Student- } \\
\text { teacher } \\
\text { relationships }\end{array}$} & $\begin{array}{l}\text { Prosocial } \\
\text { behaviour }(\mathrm{F})\end{array}$ & 0.99 & 1.59 & 1.63 & $1.95^{*}$ & $2.00 *$ & 0.91 \\
\hline & $\begin{array}{l}\text { Violent behaviour } \\
\text { (G) }\end{array}$ & 1.98 & 0.53 & 0.49 & $8.21 * *$ & $10.52 * *$ & 0.66 \\
\hline & $\begin{array}{l}\text { D vs. F } \\
t \text {-value }\end{array}$ & $7.35 * *$ & 0.05 & 0.09 & & & \\
\hline & $\begin{array}{l}\text { E vs. G } \\
t \text {-value }\end{array}$ & $2.13 * *$ & $5.67 * *$ & $4.09 * *$ & & & \\
\hline
\end{tabular}

Also, it was revealed that attitudes toward violence in two levels of relations among juvenile delinquents were different - lower (lowest in general) in student-teacher relationships compared with peer relationships, whereby polar tendencies emerge concerning with attitudes toward prosocial behaviour higher (highest in general) in student-teacher relationships compared with student-student relationships. No other statistically significant differences between the samples were revealed (Table 2).

Table 2

Students' attitudes toward violent and prosocial behaviour among student-student and teacherstudent relationships in three types of school (means, $t$-values)

\begin{tabular}{|c|c|c|c|c|c|c|c|}
\hline \multicolumn{2}{|c|}{$\begin{array}{c}\text { Attitudes toward prosocial or } \\
\text { violent behaviour }\end{array}$} & $\begin{array}{c}\text { Juvenile } \\
\text { correctional } \\
\text { institution } \\
\text { (A) }\end{array}$ & $\begin{array}{c}\text { Special } \\
\text { schools } \\
\text { (B) }\end{array}$ & $\begin{array}{c}\text { Main- } \\
\text { stream } \\
\text { schools } \\
\text { (C) }\end{array}$ & $\begin{array}{l}\text { A vs. B } \\
t \text {-value }\end{array}$ & $\begin{array}{l}\text { A vs. C } \\
t \text {-value }\end{array}$ & $\begin{array}{l}\text { B vs. C } \\
t \text {-value }\end{array}$ \\
\hline \multirow{2}{*}{$\begin{array}{l}\text { Student- } \\
\text { student } \\
\text { relationships }\end{array}$} & $\begin{array}{l}\text { Prosocial } \\
\text { behaviour (D) }\end{array}$ & 2.62 & 3.56 & 3.66 & $7.35 * *$ & $8.14 * *$ & 0.93 \\
\hline & $\begin{array}{l}\text { Violent behaviour } \\
\text { (E) }\end{array}$ & 2.13 & 2.90 & 2.97 & $4.12 * *$ & $4.08 * *$ & 0.08 \\
\hline \multirow{4}{*}{$\begin{array}{l}\text { Student- } \\
\text { teacher } \\
\text { relationships }\end{array}$} & $\begin{array}{l}\text { Prosocial } \\
\text { behaviour }(\mathbf{F})\end{array}$ & 3.01 & 3.62 & 3.75 & $6.49 * *$ & $6.52 * *$ & 0.79 \\
\hline & $\begin{array}{l}\text { Violent behaviour } \\
\text { (G) }\end{array}$ & 1.71 & 3.02 & 3.05 & $4.91 * *$ & $4.35 * *$ & 0.07 \\
\hline & $\begin{array}{l}\text { D vs. F } \\
t \text {-value }\end{array}$ & $3.55 * *$ & 0.12 & 0.08 & & & \\
\hline & $\begin{array}{l}\text { E vs. G } \\
t \text {-value }\end{array}$ & $3.98 * *$ & 0.11 & 0.13 & & & \\
\hline
\end{tabular}

Consequently, in peer and student-teacher relations in both school settings - mainstream and special schools, the frequency of prosocial behaviour was generally high and attitudes toward prosocial behaviour were positive, but in juvenile correctional institutions the frequency of prosocial behaviour in student-teacher relations was lower than in peer relations and attitudes toward prosocial behaviour were more positive in student-teacher relations than in peer relations. These first findings are generally parallel with previous studies among adolescents (Carlo et al., 2003; 2011; Johnston, Krettenauer, 2011; Padilla-Walker, Carlo, 2007) showing prosocial attitude-behaviour consistency, with specifying the school context - in mainstream and in special schools.

The overall prevalence of prosocial behaviour among juvenile delinquents was lower than among adolescents in other two educational settings, with lowest ratings revealed among student-teacher relationships compared with peer relations. The result is parallel with previous studies among public 
school non-delinquent adolescents showing that good relationships with peers were negatively associated with students antisocial (included violent) behaviours and their good relationships with teachers were positively associated with their prosocial behaviours (Ma et al., 2000). Among juvenile delinquents, the prosocial attitude-behaviour relations tended to be controversial in relationship level, reflecting less frequent behaviour with more positive attitudes in student-teacher relations compared with peer relations. The present findings have important implications for the development of interventions designed to reduce antisocial behaviours and simultaneously promote more constructive prosocial behaviours in juvenile correctional institutions to teach youth the benefits of engaging in prosocial behaviours in teacher-student relations with promoting prosocial attitudes.

Present research supported previous studies (Vernberg Jacops, Hershberger, 1999; Gellman, DeluciaWaack, 2006) among public school adolescent-age students that attitudes toward violence unacceptance follow with low levels of violence (especially in student-teacher relations) among students in two types of schools - in mainstream schools and in special schools. Opposite tendencies revealed among training school students in relations levels - juvenile delinquents' attitudes toward violence in student-teacher relations were most negative and their violent behaviour in student-teacher relations was most frequent. Previous studies (Simane-Vigante, Plotka, Blumenau, 2016) have revealed also some contradictions of criminal offenders' attitudes showing that convicted adults had higher preference towards violence than adults on probation. The present result about violent attitude-behaviour inconsistency among juvenile delinquents in student-teacher relation may evoke a speculation that unfavourable attitudes among juvenile delinquents toward the use of violence may be one factor that reflects the anti-violent psychological climate in the educational correctional institution. It can be assumed that when juvenile delinquents-maintained behaviours and attitudes those were inconsistent, they would be more prone to behaviour change. Previous studies (Schumacher, Slep, 2004) around dating aggression showed that a mismatch between attitudes and behaviour may be an important catalyst for behaviour change.

It is important to note that there will be different violence preventive and intervention strategies based on the group membership in different educational settings: Violence attitude-behaviour consistency in the mainstream school and special school gives a review for attitude change with concurrent behaviour change; and in juvenile correctional institutions attitudes may facilitate behaviour that is consistent with these attitudes.

There are some limitations to the present findings. First, the cross-sectional study design limits the ability to infer causal relations and more rigorous research is needed to better infer causal directions. Second, the constructs in the present study were assessed using self-report measures and future research using multiple methods is desirable to replicate the findings. Third, although the relatively large samples were recruited across three different school settings, the findings may not be generalizable to the broader samples of adolescents in other countries.

\section{Conclusions}

The focus of the study was to provide support for the prosocial/violence attitude-behaviour consistency or inconsistency across three different school settings in two levels of relations. Key results of the study: (1) Prosocial attitude-behaviour consistency (positive attitude with high frequency of action) and violent attitude consistency (negative attitude with low frequency of action) in mainstream and special school settings; and (2) prosocial attitude-behaviour inconsistency (positive attitude with low frequency of action) and violent attitude-behaviour inconsistency (negative attitude with high frequency of action) in student-teacher relations among juvenile delinquents in correctional institutions, are giving new directions for prevention and intervention of school violence in different school settings.

The present findings may suggest that the development and support of prosocial education programs as possibilities of preventing violence may be especially helpful for juvenile delinquents in correctional institution. Specifically, when working with juvenile delinquents, the interventions may focus on more preventive measures of students' future violent behaviour with engaging in prosocial behaviours in teacher-student relations through the evoking discrepancy between adolescents' violent behaviour and attitudes as a predictor of behaviour change in area of prosocial behaviour. In contrast, interventions and prosocial education for adolescents in mainstream and special schools may focus mainly on changing youth' attitudes (towards more unaccepting) both in peer and teacher-pupils' relationships and through this promote prosocial competencies of pupils. 


\section{Bibliography}

1. Avci R., Gucray S.S. (2013). The relationships among interparental conflict, peer, media effects and the violence behaviour of adolescents: The mediator role of attitudes towards violence. Educational Sciences: Theory \& Practice, 13(4), 205-215. Retrieved from: https://pdfs.semanticscholar.org/c365/9afad550b3fa9633acf64f2d82b6726a9c19.pdf

2. Boxer P., Tisak M.S., Goldstein S.E. (2004). Is it bad to be good? An exploration of aggressive and prosocial behavior subtypes in adolescence. Journal of Youth and Adolescence, 33(2), 91-100. Retrieved from: https://pdfs.semanticscholar.org/61a4/2979dcc8bb55d8a66c18d5870124ca05b306.pdf

3. Carlo G., Crockett L.J., Wilkinson J.L., Beal S.J. (2011). The longitudinal relationships between rural adolescents' prosocial behaviors and young adult substance use. Journal of Youth Adolescence, 40(9), 1192-1202.

4. Carlo G., Hausmann A., Christiansen S., Randall B.A. (2003). Sociocognitive and behavioral correlates of a measure of prosocial tendencies for adolescents. Journal of Early Adolescence, 23, 107-134. Retrieved from: https://pdfs.semanticscholar.org/6416/469ff7bd523cd1ab01cd6c163e9d53863eff.pdf

5. Carlo G., Koller S.H., Eisenberg N., Da Silva M.S., Frohlich C.B. (1996). A cross-national study on the relations among prosocial moral reasoning, gender role orientations, and prosocial behaviors. Developmental Psychology, 32(2), 231-240.

6. Carlo G., Mestre M.V., McGinley M.M., Tur-Porcar A., Samper P., Opal D. (2014). The protective role of prosocial behaviors on antisocial behaviors: The mediating effects of deviant peer affiliation. Journal of Adolescence, 37(4), 359-366.

7. Connor D.F. (2002). Aggression and antisocial behavior in children and adolescents: Research and treatment. New York: The Guilford Press.

8. Eisenberg N. (1996). Development of prosocial behavior. In E. De Corte, F. E., Weinert (Eds.), International encyclopedia of developmental and instructional psychology. Oxford: Pergamon Press, 206-209.

9. Eisenberg N., Carlo G., Murphy B., Van Court P. (1995). Prosocial development in late adolescence: A longitudinal study. Child Development, 66, 1179-1197. Retrieved from: https://pdfs.semanticscholar.org/2fa0/1f64506119ef1b65a2521a30fe346964a908.pdf

10. Gellman R.A., Delucia-Waack J.L. (2006). Predicting school violence: A comparison of violent and nonviolent male students on attitudes toward violence, exposure level to violence, and PTSD symptomatology. Psychology in the Schools, 43(5), 591-598.

11. Hawley P.H. (2003). Prosocial and coercive configurations of resource control in early adolescence: A case for the well-adapted Machiavellian. Merrill-Palmer Quarterly, 49(3), 279-309.

12. Johnston M., Krettenauer T. (2011). Moral self and moral emotion expectancies as predictors of anti- and prosocial behaviour in adolescence: A case for mediation? European Journal of Developmental Psychology, 8(2), 228-243.

13. Kokko K., Tremblay R.E., Lacourse E., Nagin D.S., Vitaro F. (2006). Trajectories of prosocial behavior and physical aggression in middle childhood: Links to adolescent school dropout and physical violence. Journal of Research on Adolescence, 16(3), 403-428.

14. Kornbluh M., Neal J.W. (2016). Examining the many dimensions of children's popularity: Interactions between aggression, prosocial behaviors, and gender. Journal of Social and Personal Relationships, 33(1), 62-80.

15. Krueger R.F., Hicks B.M., McGue M. (2001). Altruism and antisocial behavior: Independent tendencies, unique personality correlates, distinct etiologies. Psychological Science, 12(5), 397-402.

16. Koiv K. (2006). Noorukite antisotsiaalne käitumine: erinevad mustrid ja tendentsid Eestis. (Antisocial behavior among adolescents: Different patterns and tendencies.) In H. Haljasorg (Ed.), Piiril, Tallinn: Maarjamaa Konvent, 23-32 (in Estonian).

17. Koiv K. (2014). Comparison and connections between school climate, school safety and adolescents' antisocial behavior across three types of schools. Social Education/ Socialinis ugdymas, 38(2), 160-170.

18. Ma H.K., Shek D.T.L., Cheung P.C., Lam C.O.B. (2000). Parental, peer, and teacher influences on the social behavior of Hong Kong Chinese adolescents. The Journal of Genetic Psychology, $16(1), 65-78$. 
19. McGinley M., Carlo G. (2007). Two sides of the same coin? The relations between prosocial and physically aggressive behaviors. Journal of Youth and Adolescence, 36(3), 337-349.

20. Moffitt T.E. (1993). Adolescence-limited and life-course-persistent antisocial behavior: A developmental taxonomy. Psychological Review, 100(4), 674-701. Retrieved from: http://users.soc.umn.edu/ uggen/Moffitt_PR_93.pdf

21. Moffitt T.E., Caspi A., Rutter M., Silva P.A. (2001). Sex differences in antisocial behavior: Conduct disorder, delinquency, and violence in the Dunedin longitudinal study. Cambridge, UK: Cambridge University Press.

22. Nagin D.S., Farrington D.P., Moffitt T.E. (1995). Life-course trajectories of different types of offenders. Criminology, 33(1), 111-139.

23. Padilla-Walker L.M., Carlo G. (2007). Personal values as a mediator between parent and peer expectations and adolescent behaviors. Journal of Family Psychology, 21, 538-541.

24. Pakaslahti L., Keltikangas-Jarvinen L. (2001). Peer-attributed prosocial behaviour among aggressive/preferred, aggressive/non-preferred, non-aggressive/preferred, nonaggressive/ nonpreferred adolescents. Personality and Individual Differences, 30(6), 903-916.

25. Pulkkinen L., Tremblay R.E. (1992). Patterns of boys' social adjustment in two cultures and at different ages: A longitudinal perspective. International Journal of Behavioural Development, 15(4), 527-553.

26. Radke-Yarrow M., Zahn-Waxler C., Chapman M. (1983). Children's prosocial dispositions and behavior. In P. H. Mussen (Series Ed.), E. M. Hetherington (Vol. Ed.), Handbook of child psychology: Vol 4. Socialization, personality, and social development. New York: Wiley, 469-545.

27. Schumacher J.A., Slep A.M.S. (2004). Attitudes and dating aggression: A cognitive dissonance approach. Prevention Science, 5(4), 231-243.

28. Smith P.K. (Ed.). (2003). Violence in schools: The response in Europe. USA and Canada: RoutledgeFalmer.

29. Stams G.J.M.M., Brugman D., Dekovic M., van Rosmalen L., van der Laan P., Gibbs J.C. (2006). The moral judgment of juvenile delinquents: A metaanalysis. Journal of Abnormal Child Psychology, 34, 697-713.

30. Simane-Vigante L., Plotka I., Blumenau N. (2016). Implicit and explicit measures of antisocial attitudes of criminal offenders. In V. Dislere (Ed.), The Proceedings of the 9th International Scientific Conference Rural Environment, Education, Personality (REEP-2016), 9. Jelgava: LLU TF, 309-314. Retrieved from: http://lufb.llu.lv/conference/REEP/2016/Latvia-Univ-AgricultREEP-2016proceed2255-808X.pdf

31. Veenstra R. (2006). The development of Dr. Jekyll and Mr. Hyde: Prosocial and antisocial behavior in adolescence. In D. Fetchenhauer, A. F. B. Buunk, S. Lindenberg (Eds.), Solidarity and prosocial behavior: An integration of sociological and psychological perspectives, Berlin: Springer, 93-108.

32. Veenstra R., Lindenberg S., Oldehinkel A.J., De Winter A.F., Verhulst F.C., Ormel J. (2008). Prosocial and antisocial behavior in preadolescence: Teachers' and parents' perceptions of the behavior of girls and boys. International Journal of Behavioral Development, 32(3), 243-251.

33. Vernberg E.M., Jacops A.K., Hershberger S.L. (1999). Peer victimization and attitudes about violence during early adolescence. Journal of Clinical Child Psychology, 28(3), 386-395.

34. Wyatt J.M., Carlo G. (2002). What will my parents think? Relations among adolescents' expected parental reactions, prosocial moral reasoning, and prosocial and antisocial behaviors. Journal of Adolescent Research, 17(6), 646-666. 